\section{A 11702 788832}

NATL INST OF STANOARDS \& TECH A.I.C

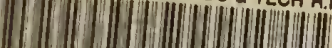

A11 102788832

RUUIVL-ROBIN MEASUREMENTS OF THE APPARENT THERMAL CONDUCTIVITY

OF TWO REFRACTORY INSULATION MATERIALS, USING HIGH-TEMPERATURE GUARDED-HOT-PLATE APPARATUS

Jerome G. Hust

David R. Smith

National Bureau of Standards

U.S. Department of Commerce

Boulder, Colorado 80303-3328

April 1988

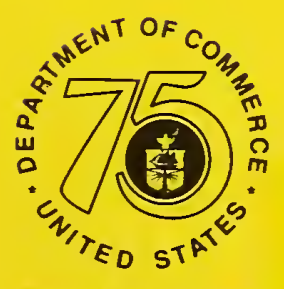

$Q C$

100

Stimulating America's Progress 1913.1988

.456

\#88-3087

1988

c. 2 


$$
\infty
$$




\section{ROUND-ROBIN MEASUREMENTS OF THE APPARENT THERMAL CONDUCTIVITY OF TWO REFRACTORY INSULATION MATERIALS, USING HIGH-TEMPERATURE GUARDED-HOT-PLATE APPARATUS}

Jerome G. Hust David R. Smith

Chemical Engineering Science Division

Center for Chemical Engineering

National Engineering Laboratory

National Bureau of Standards

Boulder, Colorado 80303-3328

April 1988

Sponsored, in part, by

U.S. Department of Energy

Oak Ridge National Laboratory

Oak Ridge, Tennessee 37830

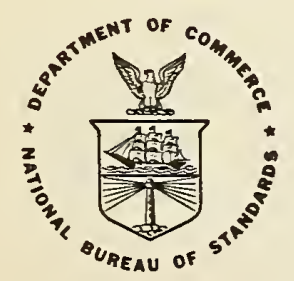

U.S. DEPARTMENT OF COMMERCE, C. William Verity, Secretary 



\title{
Round-Robin Measurements of the Apparent Thermal Conductivity of Two Refractory Insulation Materials, Using Bigh-Temperature Guarded-Bot-Plate Apparatus
}

\author{
Jerome G. Hust \\ and \\ David R. Smith
}

Center for Chemical Engineering National Engineering Laboratory

National Bureau of Standards

Boulder, CO 80303-3328

This report presents the test results and analysis of round-robin measurements of apparent thermal conductivity for two kinds of refractory insulation board using high-temperature guarded-hotplate apparatus. The round robin was carried out under the sponsorship of the American Society for Testing and Materials (ASTM) Subcommittee C-16.30 on Thermal Measurements. To complete the measurement program in a timely manner the participants chose to measure different specimens, selected, however, from the same production lot. The test results for apparent thermal conductivity illustrate the interlaboratory reproducibility as well as the temperature and density dependence. The data include the temperature range from 297 to $773 \mathrm{~K}$. The standard deviation is $7.4 \%$ for the 48 test results reported by seven participating laboratories for fibrous alumina-silica. The standard deviation is $8.0 \%$ for the 58 test results reported for calcium silicate.

Key words: apparent thermal conductivity; guarded-hot-plate apparatus; high-temperature; refractory thermal insulation; round robin.

This work was funded, in part, by DOE/ORNL under contract ORNL/IA21428 . 


\section{Introduction}

During the last 20 years considerable progress has been made in developing and improving equipment and techniques for measuring the thermal resistance of thermal insulations, particularly at ambient temperatures. However, recent unpublished intercomparisons of measurements of apparent thermal conductivity obtained with the C177 test method [1] suggest that considerably larger uncertainties may exist in measurements made with apparatus designed for higher temperatures. As a consequence, a task group was formed under the auspices of the American Society of Testing and Materials, Subcommittee C-16.30, to perform a round-robin measurement program using guarded-hot-plate apparatus at temperatures between ambient and about $775 \mathrm{~K}(500 \circ \mathrm{C})$.

Because of the urgency of the need for this information, the original plan, formulated in the fall of 1986, was to include only three laboratories in the study. However, as interest grew the task force decided in the spring of 1987 to include other laboratories, as long as they finished the measurements by July of 1987. The objective was to have the preliminary analysis completed by the 1987 fall ASTM meeting in Toronto, Canada. Such an ambitious schedule for a round robin seemed unrealistic at the time, but because of the intense interest and cooperation of the participants the schedule has been achieved.

The participants in this round robin did not measure the same specimen. Experience indicates that it usually takes a year or longer for a single specimen to make the rounds of each laboratory. Instead, round-robin specimens chosen from the same production lot of one manufacturer were distributed to the participants at the same time. This was felt by the participants to be desirable in order to obtain data for comparing the performance of the different laboratories in a timely manner.

\section{Scope}

This report presents the results and analysis of apparent thermal conductivity data obtained on two refractory insulation boards: calcium silicate of two nominal densities and a fibrous aluminasilica insulation. The fibrous alumina-silica is also under consideration for use as a Standard Reference Material (SRM) of thermal resistance [2].

The specimens of these materials were supplied by two of the participants. Prior to shipping the specimens to the participants, the bulk density of each specimen was measured at the National Bureau of Standards, Boulder, Colorado (NBS/B). After the specimens were measured by the participants and returned to NBS/B, the apparent thermal conductivity of each specimen was measured at $333 \mathrm{~K}$ using the NBS/B high-temperature guarded-hotplate apparatus in the single-sided mode. 
The plate sizes of the guarded-hot-plate apparatus used by the participants are listed in Table 1. The direction of heat flow was vertical for each of the apparatus with the exception of that having a plate diameter of $40.6 \mathrm{~cm}$; for it the direction of heat flow was horizontal.

Table 1. Sizes of plates in apparatus used by seven participants in the round-robin measurement program.

\begin{tabular}{lc}
$\begin{array}{c}\text { Plate Size } \\
(\mathrm{cm})\end{array}$ & $\begin{array}{c}\text { Metered Size } \\
(\mathrm{cm})\end{array}$ \\
\hline $61.0 \times 61.0$ & - \\
$40.6 \mathrm{dia}$. & $30.5 \times 30.5$ \\
$30.5 \times 35.6$ & $20.3 \mathrm{dia}$. \\
$30.5 \times 30.5$ & $15.2 \times 15.2$ \\
$25.4 \mathrm{dia}$. & $15.2 \times 15.2$ \\
25.4 dia. & $12.7 \mathrm{dia}$. \\
20.3 dia. & $10.2 \mathrm{dia}$. \\
\hline
\end{tabular}

\section{Experimental Data}

The experimental data submitted by the participants were compiled into tabular files for analysis by computer from the standardized forms provided to the participants. Data submitted in engineering units were converted to SI units for uniformity and ease of intercomparison. Tables 2 and 3 respectively contain the data supplied by the participants for apparent thermal conductivity of fibrous alumina-silica and of calcium silicate. Throughout this report the same symbol was used to represent the data from a given participant. These symbols are listed below:

$$
\begin{array}{lll}
\text { Lab } 1=0 & \text { Lab } 2=\Delta & \text { Lab } 3=\square \\
\text { Lab } 5=8 & \text { Lab } 6=+ & \text { Lab } 7=x
\end{array} \quad \text { Lab } 4=\nabla
$$

\section{Reference Equations and Data Analysis}

For brevity, the term "thermal conductivity" will be used in place of "apparent thermal conductivity" in the following text and figures.

In the analyses below, the integral method [3] was used in fitting the equations. The deviations shown in the tables and the deviation plots are also calculated by the integral method. This was done to remove any potential inconsistency caused by the presence of both large and small temperature differences in the data set. 
When fitting curves to experimental conductivity data we used weighted least-squares fits; the weighting was chosen to minimize the sum of the squares of the relative deviations, rather than the sum of the absolute deviations. This is considered to be preferable because when measuring thermal conductivity the experimentalist tends to keep the relative (percentage) errors constant.

\subsection{Fibrous alumina-silica}

The reference equation used to analyze the round-robin data for the fibrous alumina-silica specimens was based on measurements of thermal conductivity performed by NBS on similar specimens in conjunction with an effort to establish this material as an SRM [2]. The measurements of the candidate SRM specimens were performed on the same high-temperature guarded-hot-plate apparatus at NBS/B used in measuring the round-robin specimens. The variation of thermal conductivity with temperature for the candidate SRM specimen is

$$
k=15.13+0.09489 \mathrm{~T}+2.888 \times 10^{-8} \mathrm{~T}^{3},
$$

where $\mathrm{k}$ is in $\mathrm{mW} /(\mathrm{m} \cdot \mathrm{K})$ and $\mathrm{T}$ is in $\mathrm{K}$. The coefficients in eq(1) were obtained from a weighted least-squares fit of the data for a candidate SRM, for a specimen having a density of $247 \mathrm{~kg} / \mathrm{m}^{3}$, over a range of mean temperatures from 313 to $773 \mathrm{~K}$. Since the densities of the participants' round-robin specimens varied from 207 to $237 \mathrm{~kg} / \mathrm{m}^{3}$, we assume that the dependence of thermal conductivity on temperature for the round-robin specimens should be similar to that of the SRM candidate material.

Equation (1) was fitted to the participants' uncorrected data listed in table 2, with a multiplicative coefficient determined by a weighted least-squares fit to be 1.057 . These data, along with the fitted curve, eq(2), are shown in figure 1. The deviations of the data from the curve are shown in figure 2. The standard deviation of the data from the curve is $9.4 \%$.

$$
k=1.057\left(15.13+0.09489 \mathrm{~T}+2.888 \times 10^{-8} \mathrm{~T}^{3}\right),
$$

with $k$ defined by this correlation for T varying from 313 to $773 \mathrm{~K}$.

The data shown in figures 1 and 2 contain two broad classes or components of variability, assumed to be independent. One component is due to the variability of measurement among different apparatus and associated procedures, and the other is due to variability among the specimens. It is desirable to minimize the 
second component (specimen variability) so that the variability can be accurately determined for the different apparatus used by the participants in the round robin. NBS measured the thermal conductivity of each round-robin specimen at a temperature of 333 $K$ to permit correcting for the variability among specimens. The resulting data (thermal conductivity measured by NBS) are listed in table 4 .

To perform these corrections, the mean value of the NBS data was first obtained. The mean value of thermal conductivity for the specimens used in the round robin (last thirteen results listed in table 4$)$ is $49.847 \mathrm{~mW} /(\mathrm{m} \cdot \mathrm{K})$. Next we calculated the percentage difference between the thermal conductivity of each participant's specimen (or pair, more commonly) as measured by NBS, and the mean value of the NBS data for all specimens. These percentage corrections, listed in table 6 , represent estimates of the specimen variability and were applied to the participants' reported data to remove the effect of this variability. For example, if the thermal conductivity of a given specimen, as measured by NBS, deviated by $+5 \%$ from the mean value for all specimens, the value reported by the participant was corrected by dividing it by a factor of 1.05 .

Equation (1), shifted by a multiplier determined from a weighted least-squares fit to be 1.082 , was fitted to the corrected data.

The result is

$$
k=1.082\left(15.13+0.09489 \mathrm{~T}+2.888 \times 10-8 \mathrm{~T}^{3}\right) .
$$

with $\mathrm{k}$ defined by this correlation for $\mathrm{T}$ varying from 313 to $773 \mathrm{~K}$. These corrected data, along with the curve calculated from eq( 3 ), are shown in figure 3. The deviations of the corrected data from the curve are shown in figure 4 and listed in the last column of table 2. The standard deviation of these data from eq(3) is $7.4 \%$, as compared to the value of $9.4 \%$ obtained with the uncorrected data.

The correction procedure is based on two assumptions: (a) the correction is independent of temperature, and (b) the correction is independent of the metered area. The first assumption appears to be approximately valid since the reported data form a family of curves that with one exception are parallel to each other. Data reported by Lab 1 are the exception. The validity of the second assumption is assessed by examining the density dependence of the NBS data at $333 \mathrm{~K}$ for the round-robin specimens. 
The specimens used to determine the density dependence ranged in density from 207 to $308 \mathrm{~kg} / \mathrm{m}^{3}$. A reference equation describing the dependence of thermal conductivity on density is given in reference [2]. This reference equation is

$$
k=41.89+0.03344 \mathrm{D} \text {, }
$$

where $k$ is in $\mathrm{mW} /(\mathrm{m} \cdot \mathrm{K})$, and $\mathrm{D}$ is in $\mathrm{kg} / \mathrm{m}^{3}$. The thermal conductivity data on which this relation is based were obtained on the NBS/B high-temperature guarded-hot-plate apparatus for 16 different specimens varying in density from 218 to $308 \mathrm{~kg} / \mathrm{m}^{3}$.

The data in table 4, including the density data, used to obtain the coefficients for eq(4), are those obtained at NBS/B by measuring each of the specimens used in the round robin. These data are illustrated in figure 5. The deviations of the data from eq(4) are shown in figure 6 and listed in the last column of table 4. It was necessary to measure six additional specimens (first six lines of table 4) to obtain information on the depen-dence of thermal conductivity on density; this was not possible using only round-robin specimens because of the large scatter in the data and the limited range of density represented by the round-robin set.

The large amount of scatter in the corrected data illustrated in figures 5 and 6 is evidence that the thermal conductivity of these alumina-silica specimens is strongly affected by characteristics other than bulk density. As a consequence, the second assumption regarding uniformity over various metered areas becomes questionable. This leads to the conclusion that the $7.4 \%$ standard deviation of the corrected data may be caused both by variability among specimens as well as procedures of participating laboratories. We are unable to separate these two components at the present time.

It has been suggested that curves of thermal conductivity vs. density for this material may have considerably different slopes at different temperatures; such a conclusion is precluded here because of insufficient information obtained in this round robin and because of the scatter in the data obtained. The desire to obtain "pilot" information quickly left little time for investigating in depth many questions arising from this study. Future round robins involving this material should be planned with time enough to investigate the reasons for the scatter seen here. 
A reference equation describing the dependence on temperature of the thermal conductivity for the calcium silicate specimens was obtained. It was based on measurements performed by NBS/B (Lab 7) on one specimen from the same lot from which the participants' round-robin specimens were chosen. The coefficients in eq(5) were obtained from a weighted least-squares fit of these data.

$$
k=68.48+0.01820 \mathrm{~T}+5.616 \times 10-8 \mathrm{~T}^{3},
$$

where $k$ is in $\mathrm{mW} /(\mathrm{m} \cdot \mathrm{K})$ and $\mathrm{T}$ is in $\mathrm{K}$. This correlation is defined for values of $\mathrm{T}$ ranging from 333 to $701 \mathrm{~K}$.

Equation (5) was fitted to the participants' uncorrected data listed in table 3, with a multiplicative coefficient determined by a weighted least-squares fit to be 1.032 . These data, along with the fitted curve, eq(6), are shown in figure 7. The deviations of the data from the curve are shown in figure 8 . The standard deviation of the data from the curve is $7.9 \%$.

$$
k=1.032\left(68.48+0.01820 \mathrm{~T}+5.616 \times 10^{-8} \mathrm{~T}^{3}\right)
$$

with $\mathrm{k}$ defined by this correlation for T varying from 313 to $773 \mathrm{~K}$ The data shown in figures 7 and 8 contain two components of variability. One is due to the apparatus measurement variability, and the other is due to specimen variability. It is desirable to minimize the second component so that the variability can be accurately determined for the different apparatus used by the round-robin participants. NBS/B measured the thermal conductivity of each round-robin specimen to permit correcting for the variability among specimens. The resulting data are listed in table 3. The same method used to perform the corrections for the previously discussed alumina-silica specimens was used at this point to obtain the corrections for the calcium silicate.

The mean value of thermal conductivity for the specimens used in the round robin (results listed in table 5) is $74.991 \mathrm{~mW} /(\mathrm{m} \cdot \mathrm{K}$ ). A value was calculated for the percentage difference between the thermal conductivity, measured by NBS/B, of each specimen (or pair) used by each participant and the mean value for the NBS/B data for all specimens. These percentage corrections, listed in table 6, representing estimates of the specimen variability, were applied to the reported data to remove the effect of this variability. 
Equation (6), shifted by a multiplier determined by a weighted least-squares fit to be 1.033 , was fitted to the corrected data. The result is

$$
k=1.033\left(68.48+0.01820 \mathrm{~T}+5.616 \times 10^{-8} \mathrm{~T}^{3}\right),
$$

defined for $T$ varying from 313 to $773 \mathrm{~K}$.

These corrected data along with the curve calculated from eq(7) are shown in figure 9 . The deviations of the data from the curve are shown in figure 10 and listed in the last column of table 3 . The standard deviation of. these data from the reference curve is $8.0 \%$.

The correction procedure is based on two assumptions: (a) the correction is independent of temperature, and (b) the correction is independent of the metered area. The first assumption appears to be reasonably valid since the reported data form a family of curves that are parallel to each other, within their scatter with one exception. Data from Lab 5 cross the fitted line as temperature increases, but otherwise lie within the scatter of the band of data.

The validity of the second assumption is assessed by examining the density dependence of the NBS/B data at $333 \mathrm{~K}$ for the round-robin specimens. The specimens used in the round robin study ranged in density from 324 to $446 \mathrm{~kg} / \mathrm{m}^{3}$. A reference equation describing the dependence of thermal conductivity on density was obtained. The reference equation chosen is

$$
k=44.37+0.07694 D \text {, }
$$

where $\mathrm{k}$ is in $\mathrm{mW} /(\mathrm{m} \cdot \mathrm{K})$, and $\mathrm{D}$ is in $\mathrm{kg} / \mathrm{m}^{3}$ and varies over the range from 324 to $446 \mathrm{~kg} / \mathrm{m}^{3}$.

The data in table 5 used to obtain the coefficients for eq(8) are those measured at NBS/B on each of the specimens used in the round robin. These data are illustrated in figure 11. The deviations of the data from eq(8) are shown in figure 12 and listed in the last column of table 5 .

From the amount of scatter illustrated in figures 11 and 12 , it is suggested that the thermal conductivity of these calcium silicate specimens is affected mainly by their bulk density and not appreciably by other characteristics as were the specimens of fibrous alumina-silica. The second assumption involves the implicit assumption that density does not vary appreciably with metered area. 
To shed light on this question, the variation of density within one large, square specimen of calcium silicate was measured. Its edges originally measured $61 \mathrm{~cm}$. It had been cut into four square pieces measuring $25.4 \mathrm{~cm}$ on each side, four rectangular pieces $25.5 \mathrm{~cm}$ by $9.8 \mathrm{~cm}$, and one square piece measuring $10 \mathrm{~cm}$ on each side. The densities of these pieces ranged from 443.5 to 449.0 $\mathrm{kg} / \mathrm{m}^{3}$, with a mean density of $447.4 \mathrm{~kg} / \mathrm{m}^{3}$ and standard deviation of $0.6 \%$. This standard deviation in density corresponds to a standard deviation of about $0.3 \%$ in apparent thermal conductivity, according to eq(8) or figure 11. This suggests that only a small portion of the $8 \%$ standard deviation of the corrected data is caused by residual variations in density of the specimens.

It is puzzling that the standard deviation for the corrected data, $8.0 \%$ is not less than that of the uncorrected data, $7.9 \%$. It is known that calcium silicate insulation board contains not only adsorbed moisture (as do all porous materials), but also water of crystallization. Adsorbed moisture can be driven off reversibly by heating a specimen to a temperature somewhat above $1000 \mathrm{C}$. Water of crystallization, on the other hand, is chemically bonded and requires higher temperatures to remove; its removal is an irreversible process. This means that the thermal conductivity obtained for this material could depend on the history of the material: its past temperature and environmental humidity could influence the amount of adsorbed moisture present as well as the amount of water of crystallization.

The fact that the correction procedure does not bring the roundrobin data closer together may be evidence of variation among different preparation and measurement procedures used by the partipants. The mean value of thermal conductivity measurements on the specimens by NBS, $75 \mathrm{~mW} /(\mathrm{m} \cdot \mathrm{K})$ at $333 \mathrm{~K}$, differed from the mean value by the participants. This mean value can be estimated from the fitted curve in figure 9 to be approximately $79 \mathrm{~mW} /(\mathrm{m} \cdot \mathrm{K})$ at $333 \mathrm{~K}$, greater by about $5 \%$ than the mean of the NBS measurements.

While specific instructions for preparation of the specimens were given to the participants in the round robin, some participants lacked the equipment required to comply with all the instructions regarding conditioning of the specimens. This might explain some of the scatter in the data about the fitted curve. In this regard, the purpose of the round robin may have been fulfilled: to compare the best efforts of the participating laboratories, as well as to learn how suitable either material would be as an SRM for high temperatures.

Figures 7 through 10 show that both the reported and the corrected data from one lab (squares) for calcium silicate are in considerable disagreement with the other data. For comparison, the standard deviation of the subset of data defined by omitting the results on calcium silicate for Lab 3 was calculated; 1 is is $6.0 \%$ for uncorrected data and $5.8 \%$ for the corrected data. 


\section{Summary and Conclusions}

Round-robin measurements of thermal conductivity are presented for two refractory insulation materials at temperatures from 297 to $773 \mathrm{~K}$. Reference equations are given describing the temperature and density dependencies of the thermal conductivity of the two materials. These equations are used to analyze the interlaboratory measurement reproducibility of the seven laboratories that participated in the round robin.

The reproducibility, as measured by two times the standard deviation of the corrected data, is $15 \%$ and $16 \%$ for fibrous alumina-silica and calcium silicate, respectively. As was suggested by previous unpublished data, this is considerably larger than the $2 \%$ reproducibility observed with ambienttemperature apparatus [4]. However, the variability of the corrected data for alumina-silica probably contains a significant portion due to residual specimen variability. This excessive residual specimen variability is a consequence of the tight schedule established for this round robin. Discussions with the participants established, however, that the round robin provided useful initial information. Any future high-temperature round robins should be preceded by careful fabrication and selection of the specimens to assure their greater uniformity and thermal stability. Even though the different laboratories had guardedplate apparatus of different sizes and shapes, it may be possible to arrange a procedure so that several labs measure the same specimen, as is usual.

After the data from the different labs were corrected there remained an equally large scatter about the fitted correlation and inconsistent dependences with temperature; this indicates that a high-temperature SRM for thermal resistance could be very useful to laboratories measuring apparent thermal conductivity at temperatures significantly higher than room temperature.

We gratefully acknowledge the generosity of two companies for donating the insulation specimens for this round robin: Manville Corporation of Denver, CO, for donating the alumina-silica specimens, and PABCO of Fruita, CO, for donating the calcium silicate specimens. We also acknowledge the time and effort spent by the participating laboratories: CertainTeed Corporation, Blue Bell, PA; Dynatech R/D Company, Cambridge, MA; Fiberglas Canada, Inc., Sarnia, Ontario; Manville Corporation, Denver, CO; National Bureau of Standards, Boulder, CO; Owens/Corning Fiberglas Corporation, Granville, $\mathrm{OH}$; and PABCO, Fruita, CO. 


\section{References}

[1] ASTM Standard Test Method C177 for STEADY-STATE HEAT FLUX MEASUREMENTS AND THERMAL TRANSMISSION PROPERTIES BY MEANS OF THE GUARDED-HOT-PLATE APPARATUS, ANNUAL BOOK OF ASTM STANDARDS, VOI. 04.06, pp. 21-36 (ASTM, Philadelphia, 1986)

[2] Hust, Jerome G. and Smith, David R., Fibrous alumina-silica insulation board as a candidate Standard Reference Material, to be published as an NBSIR

[3] Hust, J. G. and Lankford, A. B., Comments on the measurement of thermal conductivity and presentation of a thermal conductivity integral method, International Journal of Thermophysics, Vol. 3, No. 1, pp. $67-77,1982$

[4] Hust, J. G. and Pelanne, C. M., Round robins on the apparent thermal conductivity of low-density glass fiber insulations using guarded hot plate and heat flow meter apparatus, U.S. Nat. Bur. Stand. NBSIR 85-3026 (1985) 
Toble 2. Round-robin thermol conductivity doto for fibrous oluminosilico.

\begin{tabular}{|c|c|c|c|c|c|c|c|}
\hline $\begin{array}{l}\text { Lob. } \\
\text { No. }\end{array}$ & $\begin{array}{l}\text { Specimen } \\
\text { Ident. }\end{array}$ & $\begin{array}{l}\text { Test } \\
\text { Density } \\
(\mathrm{kg} / \mathrm{m} 3) \\
\end{array}$ & $\begin{array}{l}\text { High } \\
\text { Temp. } \\
\text { (K) }\end{array}$ & $\begin{array}{c}\text { Low } \\
\text { Temp. } \\
(\mathrm{K})\end{array}$ & $\begin{array}{c}\text { Meon } \\
\text { Temp. } \\
(\mathrm{K})\end{array}$ & $\begin{array}{l}\text { Thermal } \\
\text { Conduct. } \\
\text { ( } \mathrm{mW} / \mathrm{m} . \mathrm{K} \text { ) }\end{array}$ & $\begin{array}{l}\text { Pet. } \\
\text { Dev. }\end{array}$ \\
\hline $\begin{array}{l}1 \\
1 \\
1\end{array}$ & $\begin{array}{l}17 A 20 \\
17 A 20 \\
17 A 20\end{array}$ & $\begin{array}{l}232.3 \\
232.3 \\
232.3\end{array}$ & $\begin{array}{l}672.039 \\
787.039 \\
443.650\end{array}$ & $\begin{array}{l}623.150 \\
742.761 \\
392.706\end{array}$ & $\begin{array}{l}647.594 \\
764.900 \\
418.178\end{array}$ & $\begin{array}{l}85.019 \\
93.089 \\
69.889\end{array}$ & $\begin{array}{l}-1.34 \\
-9.37 \\
20.28\end{array}$ \\
\hline $\begin{array}{l}2 \\
2 \\
2 \\
2 \\
2 \\
2 \\
2 \\
2\end{array}$ & $\begin{array}{l}\text { OAA24 } \\
\text { OOA24 } \\
\text { OOA24 } \\
\text { OOA24 } \\
\text { OOA22 } \\
\text { OOA22 } \\
\text { OOA22 } \\
\text { OOA22 }\end{array}$ & $\begin{array}{l}237.7 \\
237.7 \\
237.7 \\
237.7 \\
241.7 \\
241.7 \\
241.7 \\
241.7\end{array}$ & $\begin{array}{l}361.533 \\
504.844 \\
669.956 \\
598.933 \\
364.872 \\
504.444 \\
669.800 \\
599.456\end{array}$ & $\begin{array}{l}311.283 \\
453.744 \\
619.522 \\
547.856 \\
314.644 \\
453.450 \\
619.578 \\
548.217\end{array}$ & $\begin{array}{l}336.408 \\
479.294 \\
644.739 \\
573.394 \\
339.758 \\
478.947 \\
644.689 \\
573.836\end{array}$ & $\begin{array}{r}55.997 \\
74.601 \\
100.265 \\
79.039 \\
55.954 \\
74.154 \\
96.518 \\
80.436\end{array}$ & $\begin{array}{r}8.78 \\
9.39 \\
11.58 \\
-1.40 \\
4.35 \\
5.21 \\
3.88 \\
-3.04\end{array}$ \\
\hline $\begin{array}{l}3 \\
3 \\
3 \\
3 \\
3 \\
3\end{array}$ & $\begin{array}{l}05 A 07 \\
05 A 07 \\
05 A 07 \\
05 A 07 \\
05 A 07 \\
05 A 07\end{array}$ & $\begin{array}{l}218.2 \\
218.2 \\
218.2 \\
218.2 \\
218.2 \\
218.2\end{array}$ & $\begin{array}{l}497.761 \\
597.039 \\
697.594 \\
796.261 \\
623.150 \\
673.539\end{array}$ & $\begin{array}{l}447.261 \\
547.317 \\
648.650 \\
746.372 \\
522.817 \\
474.428\end{array}$ & $\begin{array}{l}472.511 \\
572.178 \\
673.122 \\
771.317 \\
572.983 \\
573.983\end{array}$ & $\begin{array}{l}58.216 \\
70.321 \\
81.417 \\
92.656 \\
67.439 \\
68.015\end{array}$ & $\begin{array}{r}-9.59 \\
-8.05 \\
-9.27 \\
-10.73 \\
-11.97 \\
-11.51\end{array}$ \\
\hline $\begin{array}{l}4 \\
4 \\
4 \\
4 \\
4 \\
4 \\
4 \\
4\end{array}$ & $\begin{array}{l}O 2 A 12 \\
02 A 12 \\
O 2 A 12 \\
O 2 A 12 \\
O 2 A 12 \\
O 2 A 12 \\
O 2 A 12 \\
O 2 A 12\end{array}$ & $\begin{array}{l}225.9 \\
225.9 \\
225.9 \\
225.9 \\
225.9 \\
225.9 \\
225.9 \\
225.9\end{array}$ & $\begin{array}{l}308.094 \\
354.928 \\
365.317 \\
392.539 \\
427.650 \\
528.039 \\
552.983 \\
391.094\end{array}$ & $\begin{array}{l}286.317 \\
324.872 \\
315.761 \\
292.206 \\
326.594 \\
327.483 \\
303.372 \\
291.372\end{array}$ & $\begin{array}{l}297.206 \\
339.900 \\
340.539 \\
342.372 \\
377.122 \\
427.761 \\
428.178 \\
341.233\end{array}$ & $\begin{array}{l}53.605 \\
59.369 \\
58.937 \\
58.937 \\
63.548 \\
69.168 \\
69.024 \\
57.496\end{array}$ & $\begin{array}{l}4.56 \\
5.24 \\
4.32 \\
3.87 \\
4.12 \\
2.38 \\
1.97 \\
1.58\end{array}$ \\
\hline $\begin{array}{l}5 \\
5 \\
5 \\
5 \\
5 \\
5 \\
5 \\
5 \\
5\end{array}$ & $\begin{array}{l}23 A 25 \\
23 A 25 \\
23 A 25 \\
23 A 25 \\
23 A 25 \\
23 A 25 \\
23 A 25 \\
23 A 25 \\
23 A 25\end{array}$ & $\begin{array}{l}219.6 \\
219.6 \\
219.6 \\
219.6 \\
219.6 \\
219.6 \\
219.6 \\
219.6 \\
219.6\end{array}$ & $\begin{array}{l}393.150 \\
493.150 \\
593.150 \\
693.150 \\
793.150 \\
423.150 \\
523.150 \\
623.150 \\
723.150\end{array}$ & $\begin{array}{l}353.150 \\
453.150 \\
553.150 \\
653.150 \\
753.150 \\
323.150 \\
423.150 \\
523.150 \\
623.150\end{array}$ & $\begin{array}{l}373.150 \\
473.150 \\
573.150 \\
673.150 \\
773.150 \\
373.150 \\
473.150 \\
573.150 \\
673.150\end{array}$ & $\begin{array}{r}57.000 \\
67.000 \\
83.000 \\
96.000 \\
115.000 \\
56.000 \\
66.000 \\
81.000 \\
99.000\end{array}$ & $\begin{array}{r}8.97 \\
5.65 \\
10.16 \\
8.76 \\
12.34 \\
7.01 \\
4.03 \\
7.46 \\
12.10\end{array}$ \\
\hline $\begin{array}{l}6 \\
6 \\
6 \\
6 \\
6\end{array}$ & $\begin{array}{l}06 A 10 \\
06 A 10 \\
06 A 10 \\
06 A 10 \\
06 A 10\end{array}$ & $\begin{array}{l}224.3 \\
224.3 \\
224.3 \\
224.3 \\
224.3\end{array}$ & $\begin{array}{l}310.983 \\
422.706 \\
561.983 \\
643.539 \\
310.428\end{array}$ & $\begin{array}{l}286.206 \\
286.817 \\
287.706 \\
288.372 \\
286.261\end{array}$ & $\begin{array}{l}298.594 \\
354.761 \\
424.844 \\
465.956 \\
298.344\end{array}$ & $\begin{array}{l}50.003 \\
56.487 \\
63.548 \\
68.159 \\
47.841\end{array}$ & $\begin{array}{l}-2.64 \\
-2.95 \\
-5.45 \\
-6.36 \\
-6.80\end{array}$ \\
\hline $\begin{array}{l}7 \\
7 \\
7 \\
7 \\
7 \\
7 \\
7 \\
7 \\
7 \\
7\end{array}$ & $\begin{array}{l}21 A 30 \\
D X A 30 \\
28 A 30 \\
28 A 30 \\
28 A 30 \\
28 A 30 \\
28 A 30 \\
28 A 30 \\
28 A 30 \\
28 A 30\end{array}$ & $\begin{array}{l}237.0 \\
247.0 \\
247.2 \\
247.0 \\
246.8 \\
246.5 \\
246.3 \\
246.1 \\
245.8 \\
245.6\end{array}$ & $\begin{array}{l}343.294 \\
323.055 \\
383.227 \\
463.157 \\
562.750 \\
662.267 \\
603.096 \\
653.224 \\
712.137 \\
763.373\end{array}$ & $\begin{array}{l}323.089 \\
303.134 \\
363.068 \\
383.201 \\
383.205 \\
402.976 \\
562.959 \\
613.126 \\
672.899 \\
728.645\end{array}$ & $\begin{array}{l}333.192 \\
313.095 \\
373.148 \\
423.179 \\
472.978 \\
532.622 \\
583.028 \\
633.175 \\
692.518 \\
746.009\end{array}$ & $\begin{array}{l}52.767 \\
45.769 \\
51.939 \\
57.251 \\
62.786 \\
69.619 \\
75.939 \\
82.732 \\
91.822 \\
96.895\end{array}$ & $\begin{array}{r}6.70 \\
-3.22 \\
-3.50 \\
-3.72 \\
-3.91 \\
-4.23 \\
-3.62 \\
-3.10 \\
-1.83 \\
-4.32\end{array}$ \\
\hline
\end{tabular}


Table 3. Round-robin thermal conductivity data for calcium silicate.

\begin{tabular}{|c|c|c|c|c|c|c|c|}
\hline $\begin{array}{l}\text { Lab. } \\
\text { No. }\end{array}$ & $\begin{array}{l}\text { Specimen } \\
\text { Ident. }\end{array}$ & $\begin{array}{l}\text { Test } \\
\text { Density } \\
(\mathrm{kg} / \mathrm{m} 3)\end{array}$ & $\begin{array}{l}\text { High } \\
\text { Temp. } \\
\text { (K) }\end{array}$ & $\begin{array}{l}\text { Low } \\
\text { Temp. } \\
\text { (K) }\end{array}$ & $\begin{array}{l}\text { Mean } \\
\text { Temp. } \\
\text { (K) }\end{array}$ & $\begin{array}{l}\text { Thermal } \\
\text { Conduct. } \\
\text { (mw/m.k) }\end{array}$ & $\begin{array}{l}\text { Pct. } \\
\text { Dev. }\end{array}$ \\
\hline $\begin{array}{l}1 \\
1 \\
1 \\
1\end{array}$ & $\begin{array}{l}\text { 6A8M12 } \\
6 A 8 M 12 \\
6 A 8 M 12 \\
6 A 8 M 12\end{array}$ & $\begin{array}{l}443.7 \\
443.7 \\
443.7 \\
443.7\end{array}$ & $\begin{array}{l}757.539 \\
648.261 \\
529.983 \\
430.650\end{array}$ & $\begin{array}{l}729.872 \\
617.261 \\
495.372 \\
392.539\end{array}$ & $\begin{array}{l}743.706 \\
632.761 \\
512.678 \\
411.594\end{array}$ & $\begin{array}{r}119.891 \\
108.507 \\
98.564 \\
90.639\end{array}$ & $\begin{array}{r}8.76 \\
9.81 \\
10.08 \\
8.19\end{array}$ \\
\hline $\begin{array}{l}2 \\
2 \\
2 \\
2 \\
2 \\
2 \\
2 \\
2\end{array}$ & $\begin{array}{l}1 M 12 \\
1 M 12 \\
1 M 12 \\
1 M 12 \\
9 L 12 \\
9 L 12 \\
9 L 12 \\
9 L 12\end{array}$ & $\begin{array}{l}403.2 \\
403.2 \\
403.2 \\
403.2 \\
320.2 \\
320.2 \\
320.2 \\
320.2\end{array}$ & $\begin{array}{l}376.372 \\
503.289 \\
669.583 \\
598.967 \\
377.528 \\
503.361 \\
669.739 \\
598.656\end{array}$ & $\begin{array}{l}327.078 \\
453.111 \\
619.567 \\
548.422 \\
326.678 \\
452.367 \\
619.789 \\
547.867\end{array}$ & $\begin{array}{l}351.725 \\
478.200 \\
644.575 \\
573.694 \\
352.103 \\
477.864 \\
644.764 \\
573.261\end{array}$ & $\begin{array}{r}89.529 \\
96.706 \\
108.911 \\
95.394 \\
78.621 \\
86.374 \\
101.403 \\
85.336\end{array}$ & $\begin{array}{r}11.95 \\
12.22 \\
10.55 \\
3.02 \\
7.79 \\
9.93 \\
12.85 \\
1.10\end{array}$ \\
\hline $\begin{array}{l}3 \\
3 \\
3 \\
3\end{array}$ & $\begin{array}{l}5 A 7 M 12 \\
5 A 7 M 12 \\
5 A 7 M 12 \\
5 A 7 M 12\end{array}$ & $\begin{array}{l}450.1 \\
450.1 \\
450.1 \\
450.1\end{array}$ & $\begin{array}{l}497.650 \\
596.650 \\
694.928 \\
795.094\end{array}$ & $\begin{array}{l}446.650 \\
548.594 \\
647.317 \\
747.317\end{array}$ & $\begin{array}{l}472.150 \\
572.622 \\
671.122 \\
771.206\end{array}$ & $\begin{array}{l}70.177 \\
73.491 \\
84.875 \\
92.944\end{array}$ & $\begin{array}{l}-19.50 \\
-21.79 \\
-17.28 \\
-18.29\end{array}$ \\
\hline $\begin{array}{l}4 \\
4 \\
4 \\
4 \\
4 \\
4 \\
4 \\
4 \\
4\end{array}$ & $\begin{array}{l}1 A 2 M 24 \\
1 A 2 M 24 \\
1 A 2 M 24 \\
1 A 2 M 24 \\
1 A 2 M 24 \\
1 A 2 M 24 \\
1 A 2 M 24 \\
1 A 2 M 24\end{array}$ & $\begin{array}{l}440.5 \\
440.5 \\
440.5 \\
440.5 \\
440.5 \\
440.5 \\
440.5 \\
440.5\end{array}$ & $\begin{array}{l}308.039 \\
354.428 \\
365.594 \\
391.539 \\
427.483 \\
528.428 \\
552.094 \\
391.539\end{array}$ & $\begin{array}{l}286.317 \\
323.428 \\
316.039 \\
292.150 \\
326.761 \\
327.817 \\
305.039 \\
291.706\end{array}$ & $\begin{array}{l}297.178 \\
338.928 \\
340.817 \\
341.844 \\
377.122 \\
428.122 \\
428.567 \\
341.622\end{array}$ & $\begin{array}{l}81.849 \\
86.748 \\
85.740 \\
85.740 \\
89.054 \\
91.504 \\
91.359 \\
84.154\end{array}$ & $\begin{array}{r}.18 \\
4.13 \\
2.82 \\
2.72 \\
4.76 \\
4.30 \\
3.95 \\
.83\end{array}$ \\
\hline $\begin{array}{l}4 \\
4 \\
4 \\
4 \\
4 \\
4 \\
4 \\
4\end{array}$ & $\begin{array}{l}1 A 2 L 12 \\
1 A 2 L 12 \\
1 A 2 L 12 \\
1 A 2 L 12 \\
1 A 2 L 12 \\
1 A 2 L 12 \\
1 A 2 L 12 \\
1 A 2 L 12\end{array}$ & $\begin{array}{l}358.8 \\
358.8 \\
358.8 \\
358.8 \\
358.8 \\
358.8 \\
358.8 \\
358.8\end{array}$ & $\begin{array}{l}307.817 \\
354.594 \\
365.761 \\
391.150 \\
428.150 \\
527.817 \\
552.594 \\
391.317\end{array}$ & $\begin{array}{l}286.039 \\
324.983 \\
315.872 \\
291.372 \\
326.761 \\
327.761 \\
303.317 \\
292.483\end{array}$ & $\begin{array}{l}296.928 \\
339.789 \\
340.817 \\
341.261 \\
377.456 \\
427.789 \\
427.956 \\
341.900\end{array}$ & $\begin{array}{l}75.076 \\
79.111 \\
78.679 \\
78.390 \\
81.561 \\
85.019 \\
84.587 \\
76.661\end{array}$ & $\begin{array}{r}.87 \\
4.20 \\
3.57 \\
3.12 \\
5.30 \\
6.40 \\
5.68 \\
.81\end{array}$ \\
\hline $\begin{array}{l}5 \\
5 \\
5 \\
5 \\
5 \\
5 \\
5 \\
5 \\
5\end{array}$ & $\begin{array}{l}\text { 2A4M12 } \\
2 A 4 M 12 \\
2 A 4 M 12 \\
2 A 4 M 12 \\
2 A 4 M 12 \\
2 A 4 M 12 \\
2 A 4 M 12 \\
2 A 4 M 12 \\
2 A 4 M 12\end{array}$ & $\begin{array}{l}393.8 \\
393.8 \\
393.8 \\
393.8 \\
393.8 \\
393.8 \\
393.8 \\
393.8 \\
393.8\end{array}$ & $\begin{array}{l}393.150 \\
493.150 \\
593.150 \\
693.150 \\
793.150 \\
423.150 \\
523.150 \\
623.150 \\
723.150\end{array}$ & $\begin{array}{l}353.150 \\
453.150 \\
553.150 \\
653.150 \\
753.150 \\
323.150 \\
423.150 \\
523.150 \\
623.150\end{array}$ & $\begin{array}{l}373.150 \\
473.150 \\
573.150 \\
673.150 \\
773.150 \\
373.150 \\
473.150 \\
573.150 \\
673.150\end{array}$ & $\begin{array}{r}75.000 \\
88.000 \\
99.000 \\
110.000 \\
126.000 \\
74.000 \\
85.000 \\
95.000 \\
108.000\end{array}$ & $\begin{array}{r}-6.67 \\
3.11 \\
7.64 \\
9.36 \\
12.98 \\
-7.96 \\
-.47 \\
3.22 \\
7.29\end{array}$ \\
\hline $\begin{array}{l}6 \\
6 \\
6 \\
6\end{array}$ & $\begin{array}{l}3 A 9 M 12 \\
3 A 9 M 12 \\
3 A 9 M 12 \\
3 A 9 M 12\end{array}$ & $\begin{array}{l}405.3 \\
405.3 \\
405.3 \\
405.3\end{array}$ & $\begin{array}{l}308.317 \\
444.206 \\
570.428 \\
308.539\end{array}$ & $\begin{array}{l}286.261 \\
287.150 \\
288.039 \\
286.261\end{array}$ & $\begin{array}{l}297.289 \\
365.678 \\
429.233 \\
297.400\end{array}$ & $\begin{array}{l}73.779 \\
79.543 \\
83.866 \\
73.203\end{array}$ & $\begin{array}{r}-5.71 \\
-1.78 \\
-.53 \\
-6.45\end{array}$ \\
\hline $\begin{array}{l}7 \\
7 \\
7 \\
7 \\
7 \\
7 \\
7 \\
7 \\
7 \\
7 \\
7 \\
7 \\
7\end{array}$ & $\begin{array}{l}4 M 24 A C \\
4 M 24 A C \\
4 M 24 A C \\
4 M 24 A C \\
4 M 24 A C \\
4 M 24 A C \\
4 M 24 A C \\
4 M 24 A C \\
4 M 24 A C \\
4 M 24 A C \\
4 M 24 A C \\
4 M 24 A C \\
4 M 24 A C\end{array}$ & $\begin{array}{l}443.4 \\
443.4 \\
446.2 \\
446.0 \\
445.8 \\
445.3 \\
444.6 \\
444.0 \\
444.0 \\
443.9 \\
443.3 \\
444.6 \\
446.2\end{array}$ & $\begin{array}{l}712.221 \\
709.587 \\
343.094 \\
373.165 \\
413.320 \\
472.770 \\
572.831 \\
649.749 \\
674.786 \\
722.322 \\
714.678 \\
572.532 \\
343.097\end{array}$ & $\begin{array}{l}676.060 \\
675.964 \\
323.193 \\
343.174 \\
373.226 \\
433.164 \\
523.279 \\
599.268 \\
575.638 \\
535.621 \\
687.533 \\
523.148 \\
323.136\end{array}$ & $\begin{array}{l}694.141 \\
692.776 \\
333.144 \\
358.170 \\
393.273 \\
452.967 \\
548.055 \\
624.509 \\
625.212 \\
628.972 \\
701.106 \\
547.840 \\
333.117\end{array}$ & $\begin{array}{r}99.568 \\
100.543 \\
76.586 \\
77.854 \\
79.620 \\
82.649 \\
88.069 \\
92.888 \\
92.408 \\
94.149 \\
101.322 \\
87.593 \\
75.778\end{array}$ & $\begin{array}{l}-4.52 \\
-3.45 \\
-4.24 \\
-3.86 \\
-3.52 \\
-3.38 \\
-3.81 \\
-4.87 \\
-5.48 \\
-4.25 \\
-3.51 \\
-4.31 \\
-5.24\end{array}$ \\
\hline
\end{tabular}


Table 4. Test results for each of the round-robin alumina-silica specimens as obtained by NBS at a mean temperature of $333 \mathrm{~K}$.

\begin{tabular}{|c|c|c|c|c|c|c|}
\hline $\begin{array}{l}\text { Specimen } \\
\text { Ident. }\end{array}$ & $\begin{array}{l}\text { Test } \\
\text { Density } \\
(\mathrm{kg} / \mathrm{m} 3)\end{array}$ & $\begin{array}{l}\text { High } \\
\text { Temp. } \\
\text { (K) }\end{array}$ & $\begin{array}{l}\text { Low } \\
\text { Temp. } \\
\text { (K) }\end{array}$ & $\begin{array}{c}\text { Mean } \\
\text { Temp. } \\
\text { (K) }\end{array}$ & $\begin{array}{l}\text { Thermal } \\
\text { Conduct. } \\
\text { (mW/m.k) }\end{array}$ & $\begin{array}{l}\text { Pct. } \\
\text { Dev. }\end{array}$ \\
\hline $3-28 / 30$ & 247.3 & 343.187 & 323.111 & 333.149 & 47.771 & -5.00 \\
\hline $3-28 / 30$ & 247.4 & 343.207 & 323.167 & 333.187 & 47.973 & -4.57 \\
\hline I I -35 & 295.1 & 343.197 & 323.181 & 333.189 & 53.019 & 2.38 \\
\hline I I -36 & 295.8 & 343.108 & 323.179 & 333.144 & 53.220 & 2.70 \\
\hline IV -1 & 306.5 & 343.314 & 323.067 & 333.191 & 50.737 & -2.76 \\
\hline IV -3 & 307.7 & 343.376 & 323.117 & 333.247 & 50.622 & -3.08 \\
\hline CBRD-21 & 237.0 & 343.294 & 323.089 & 333.192 & 52.767 & 5.59 \\
\hline CBRD-22 & 221.4 & 343.399 & 323.157 & 333.278 & 50.941 & 3.23 \\
\hline CBRD-24 & 236.4 & 343.316 & 323.063 & 333.190 & 49.257 & -1.89 \\
\hline CBRD-12 & 225 & 343.232 & 323.107 & 333.170 & 54.394 & 9.11 \\
\hline CBRD -02 & 223.4 & 343.468 & 323.028 & 333.248 & 52.766 & 6.45 \\
\hline CBRD-10 & 225.0 & 343.440 & 323.069 & 333.255 & 53.653 & 7.90 \\
\hline CBRD-06 & 220.5 & 343.169 & 323.126 & 333.148 & 53.359 & 7.68 \\
\hline CBRD -17 & 220.1 & 343.154 & 323.113 & 333.134 & 46.837 & -5.15 \\
\hline CBRD-20 & 217.4 & 343.341 & 323.160 & 333.251 & 47.229 & -4.09 \\
\hline CBRD-23 & 207.2 & 343.179 & 323.082 & 333.131 & 46.464 & -5.07 \\
\hline CBRD -25 & 207.9 & 343.224 & 323.076 & 333.150 & 46.176 & -5.77 \\
\hline CBRD-05 & 214.2 & 343.506 & 323.168 & 333.337 & 48.033 & -2.12 \\
\hline CBRD-07 & 215.3 & 343.309 & 323.003 & 333.156 & 46.140 & 630 \\
\hline
\end{tabular}

Table 5. Test results for each of the round-robin calcium silicate specimens as obtained by NBS ot a mean temperature of $333 \mathrm{~K}$.

\begin{tabular}{|c|c|c|c|c|c|c|}
\hline $\begin{array}{l}\text { Specimen } \\
\text { Ident. }\end{array}$ & $\begin{array}{l}\text { Test } \\
\text { Density } \\
\text { (kg/m3) }\end{array}$ & $\begin{array}{l}\text { High } \\
\text { Temp. } \\
\text { (K) }\end{array}$ & $\begin{array}{l}\text { Low } \\
\text { Temp. } \\
\text { (K) }\end{array}$ & $\begin{array}{l}\text { Mean } \\
\text { Temp. } \\
\text { (K) }\end{array}$ & $\begin{array}{l}\text { Thermal } \\
\text { Conduct. } \\
\text { (mw/m.K) }\end{array}$ & $\begin{array}{l}\text { Pet. } \\
\text { Dev. }\end{array}$ \\
\hline $4 M 24$ & 446.2 & 343.097 & 323.136 & 333.117 & 75.778 & -3.86 \\
\hline $9\llcorner 12$ & 324.1 & 343.316 & 323.236 & 333.276 & 68.456 & -1.24 \\
\hline $1 \mathrm{M} 12$ & 386.2 & 343.129 & 323.144 & 333.137 & 75.075 & 1.32 \\
\hline $2 M 12$ & 404.5 & 343.245 & 323.145 & 333.195 & 75.177 & -.42 \\
\hline $4 M 12$ & 404.5 & 343.252 & 323.151 & 333.202 & 74.036 & -1.97 \\
\hline $2 M 24$ & 426.9 & 343.150 & 323.131 & 333.141 & 79.006 & 2.27 \\
\hline $1 M 24$ & 425.4 & 343.137 & 323.138 & 333.138 & 78.408 & 1.67 \\
\hline $2 \mathrm{~L} 12$ & 354.9 & 343.291 & 323.111 & 333.201 & 71.057 & -.87 \\
\hline $1 \mathrm{~L} 12$ & 354.4 & 343.139 & 323.125 & 333.132 & 72.357 & .99 \\
\hline $9 M 12$ & 403.4 & 343.296 & 323.084 & 333.190 & 74.631 & -1.04 \\
\hline $3 M 12$ & 400.5 & 343.149 & 323.106 & 333.128 & 76.108 & 1.21 \\
\hline $8 M 12$ & 405.1 & 343.114 & 323.097 & 333.106 & 75.701 & .21 \\
\hline $6 M 12$ & 409.8 & 343.125 & 323.126 & 333.126 & 76.554 & .85 \\
\hline $5 M 12$ & 409.3 & 343.149 & 323.140 & 333.145 & 75.785 & -.10 \\
\hline $7 M 12$ & 412.1 & 343.225 & 323.093 & 333.159 & 76.731 & .85 \\
\hline
\end{tabular}


Table 6. Percentage Corrections Applied to Reported Data to Remove Effect of Specimen Variability

\begin{tabular}{ccc} 
& \multicolumn{2}{c}{ Percentage Correction } \\
Lab No. & Alumina-Silica & Calcium Silicate \\
\hline 1 & +5.65 & -1.52 \\
$2 *$ & -2.19 & +8.71 \\
3 & +1.19 & -0.11 \\
$4 *$ & +5.54 & -1.69 \\
5 & -7.48 & +4.38 \\
6 & +7.08 & -4.96 \\
7 & -7.33 & +0.51 \\
& +4.39 & -0.51 \\
& & -1.05
\end{tabular}

*Two separate specimens were measured by lab 2 (both types of specimen) and by lab 4 (calcium silicate only) 


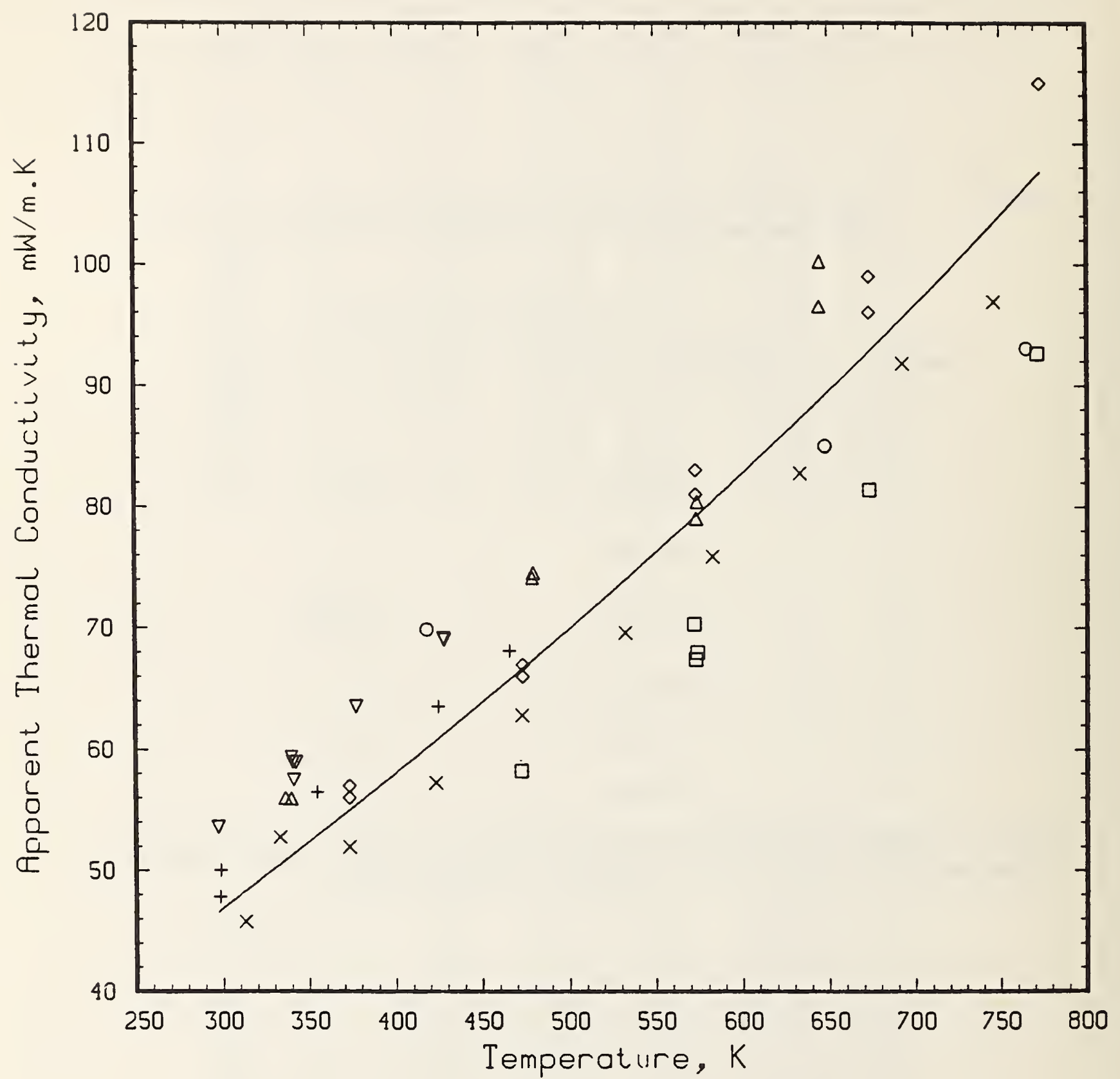

Figure 1. Thermal conductivity of round-robin specimens of fibrous alumina-silica; test densities range from 218 to $247 \mathrm{~kg} / \mathrm{m}^{3}$. The solid curve is calculated from eq (2). 


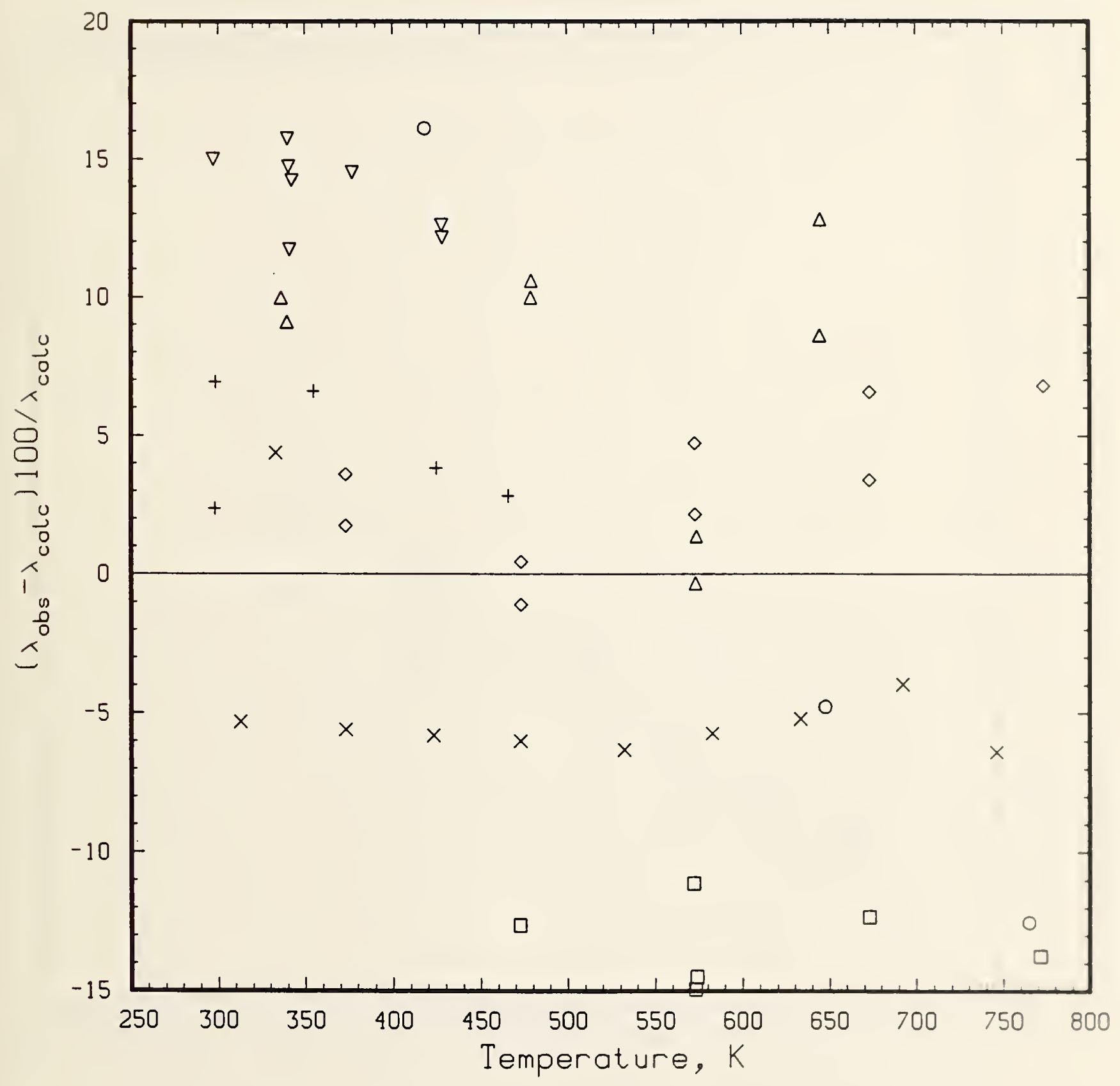

Figure 2. Deviations of thermal conductivity round-robin test results from values calculated with eq(2) for fibrous alumina-silica. 


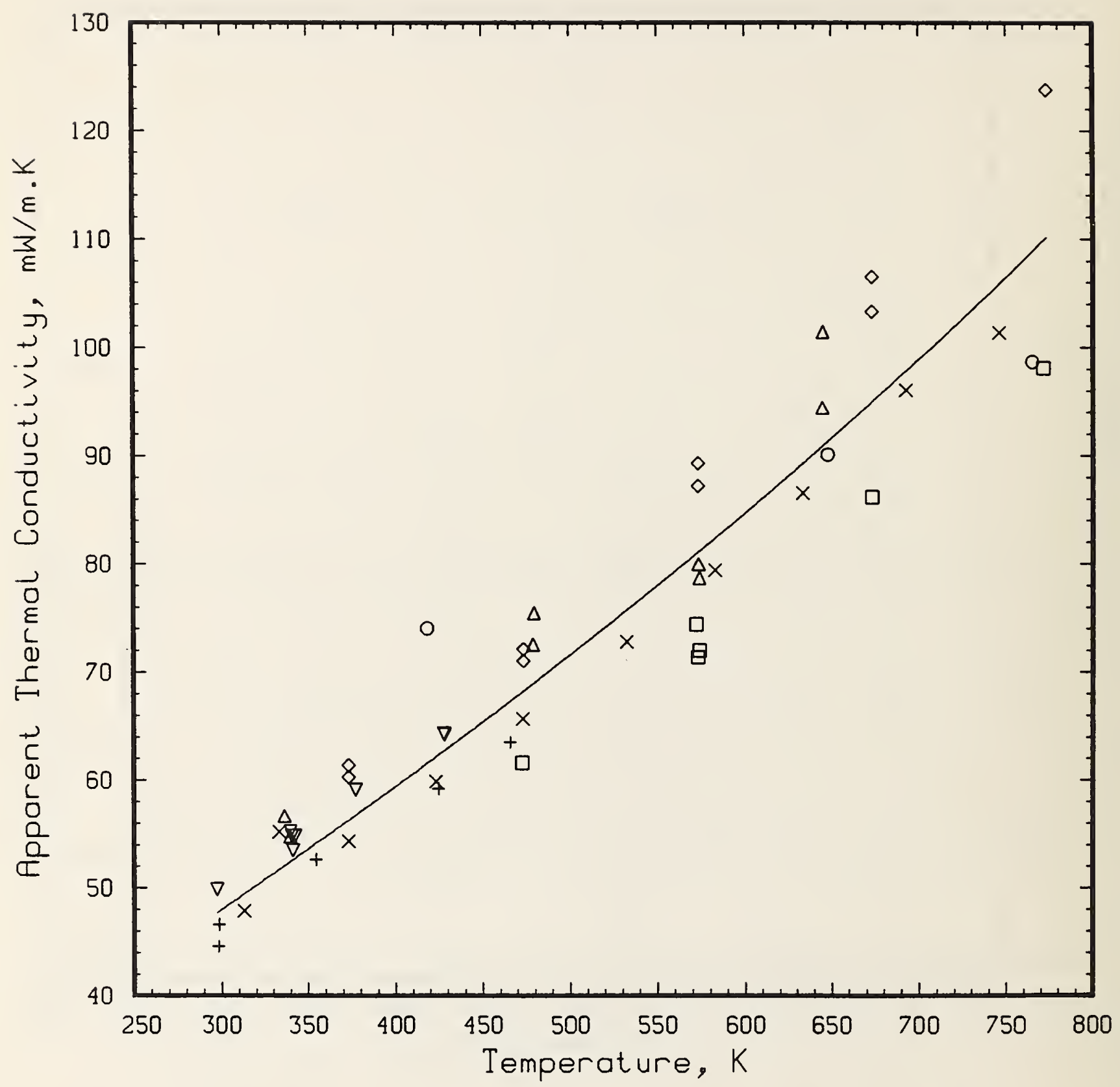

Figure 3. Thermal conductivity round-robin test results, corrected for deviation of apparent thermal conductivity from mean thermal conductivity, $49.9 \mathrm{~mW} / \mathrm{m} . \mathrm{K}$, for fibrous alumina-silica; test densities range from 218 to $247 \mathrm{~kg} / \mathrm{m}^{3}$. The solid curve is calculated from eq ( 3 ). 


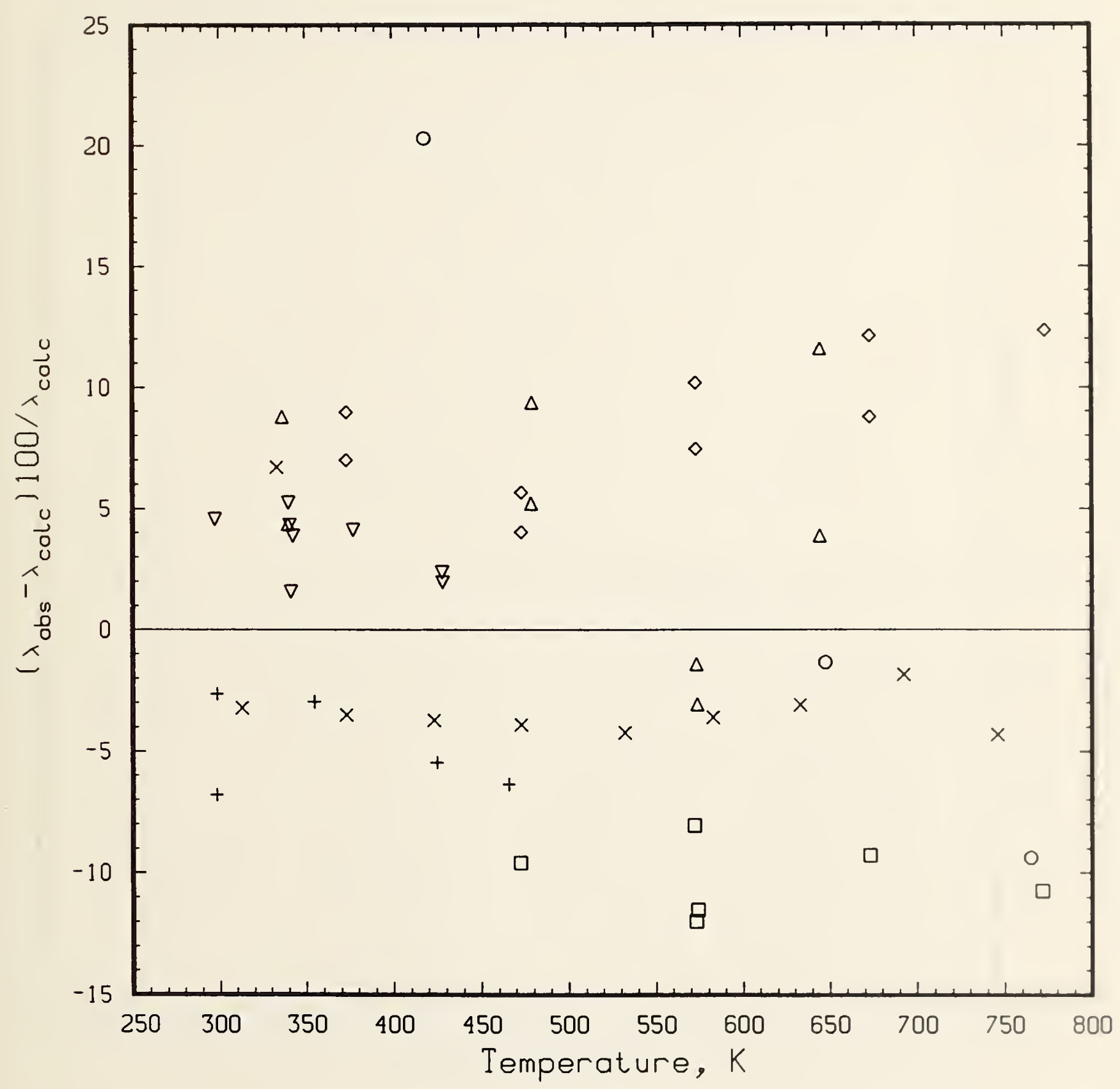

Figure 4. Deviations of corrected thermal conductivity roundrobin test results from values calculated with eq (3) for fibrous alumina-silica. 


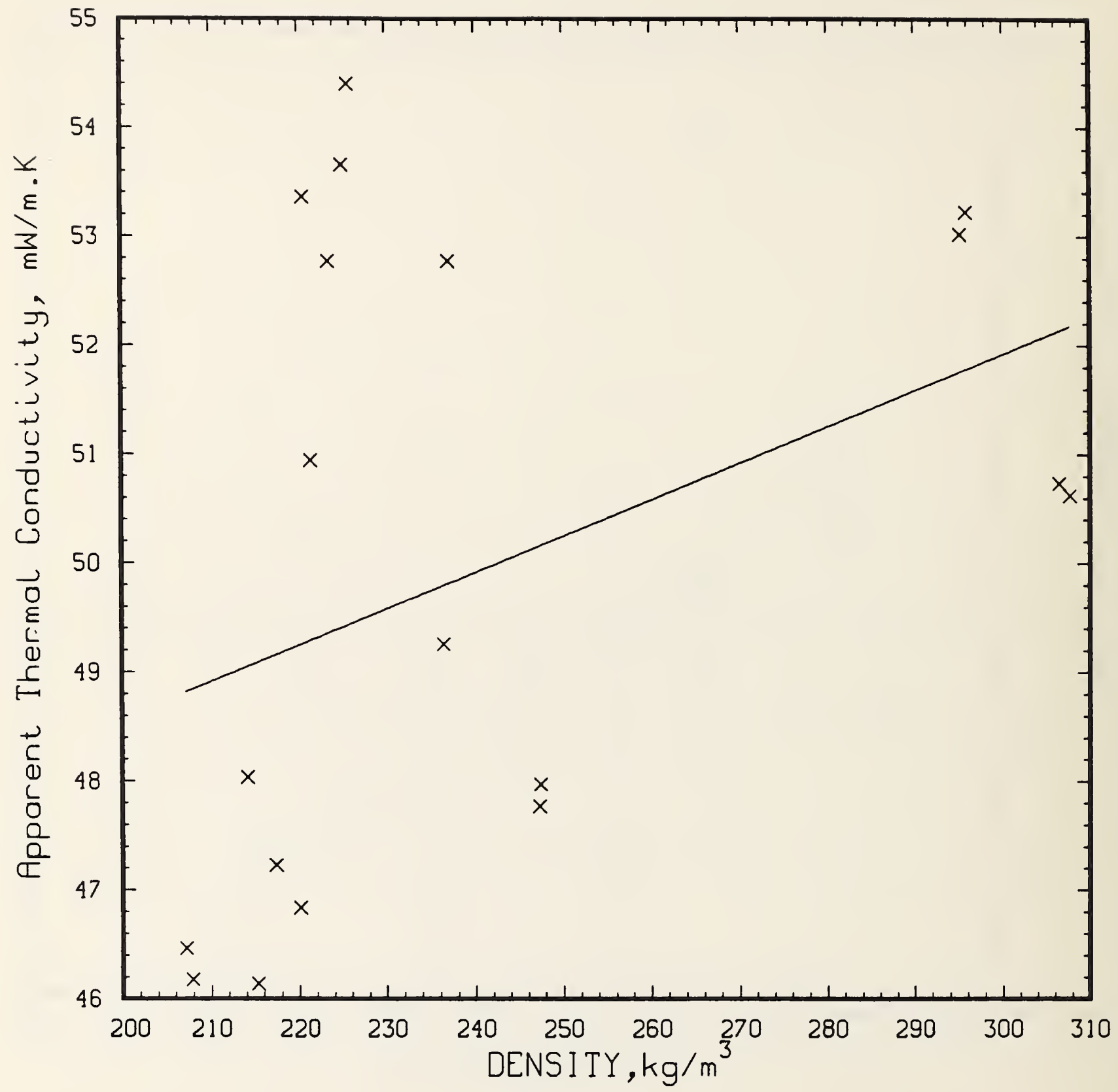

Figure 5. Thermal conductivity of round-robin specimens of fibrous alumina-silica as measured by NBS at a mean temperature of $333 \mathrm{~K}$. The solid curve is calculated from eq (4). 


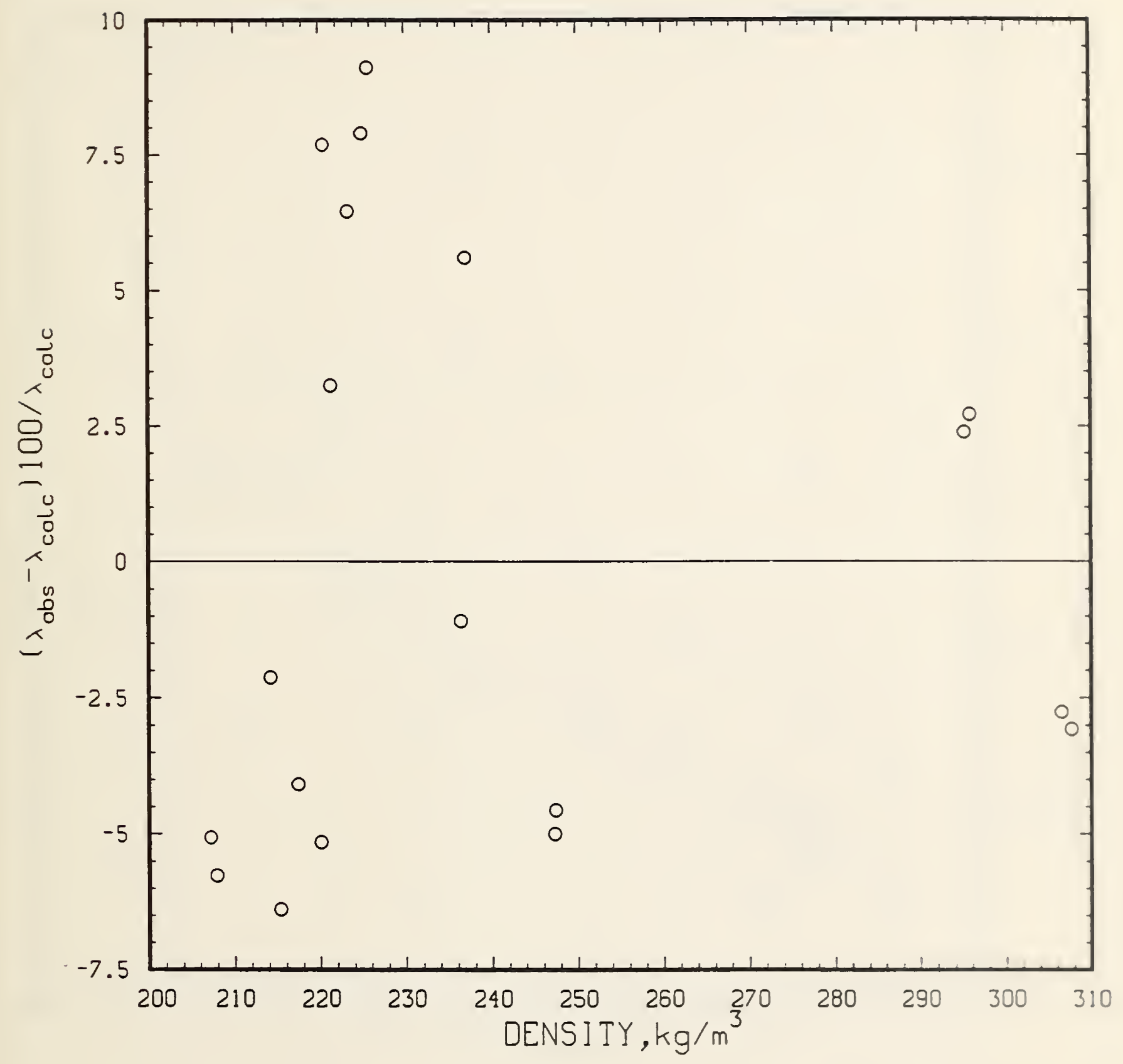

Figure 6. Deviations of thermal conductivity of round-robin specimens of fibrous alumina-silica from values calculated with eq (4). 


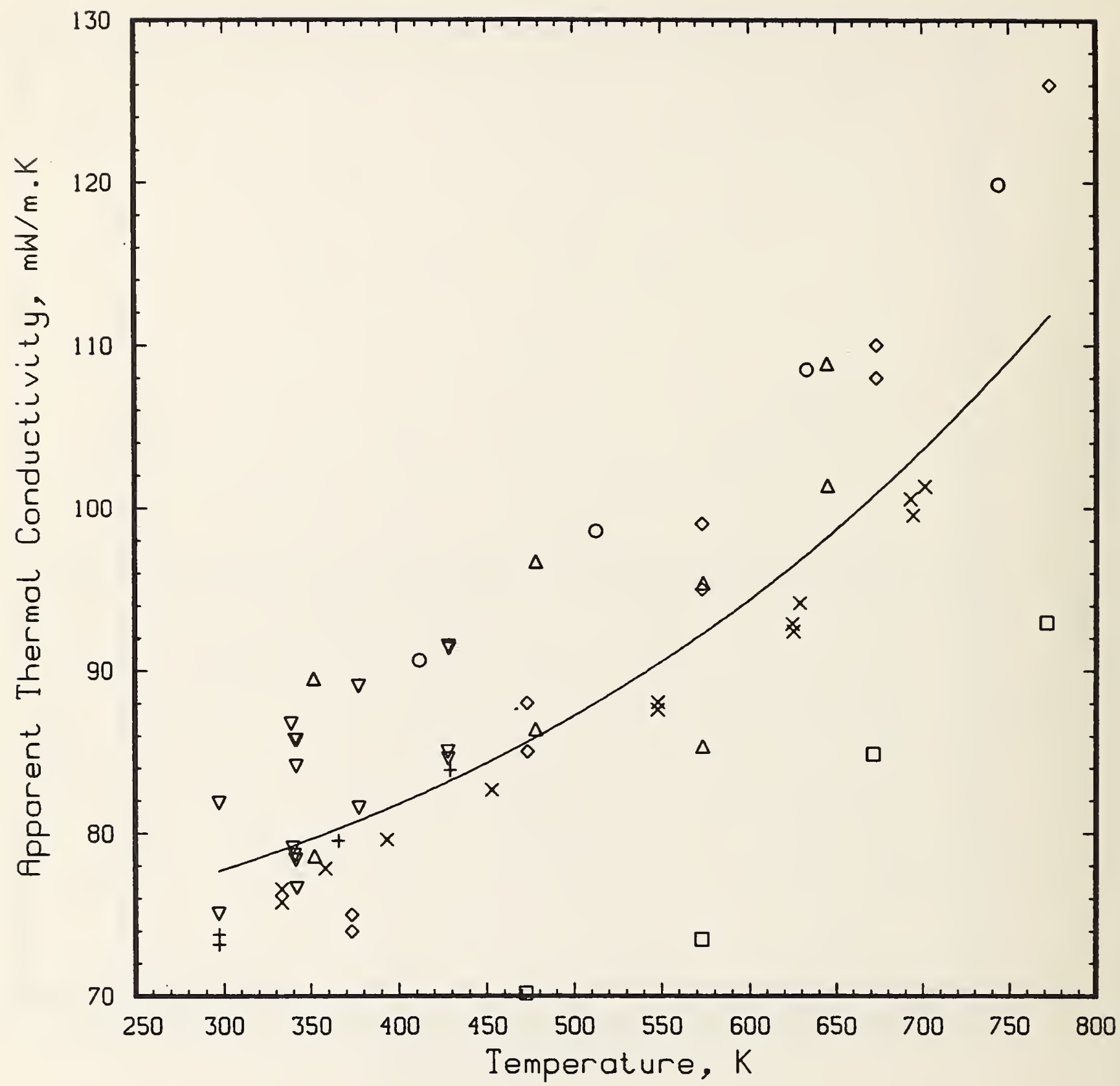

Figure 7. Thermal conductivity of round-robin specimens of calcium silicate; test densities range from 320 to 450 $\mathrm{kg} / \mathrm{m}^{3}$. The solid curve is calculated from eq (6). 


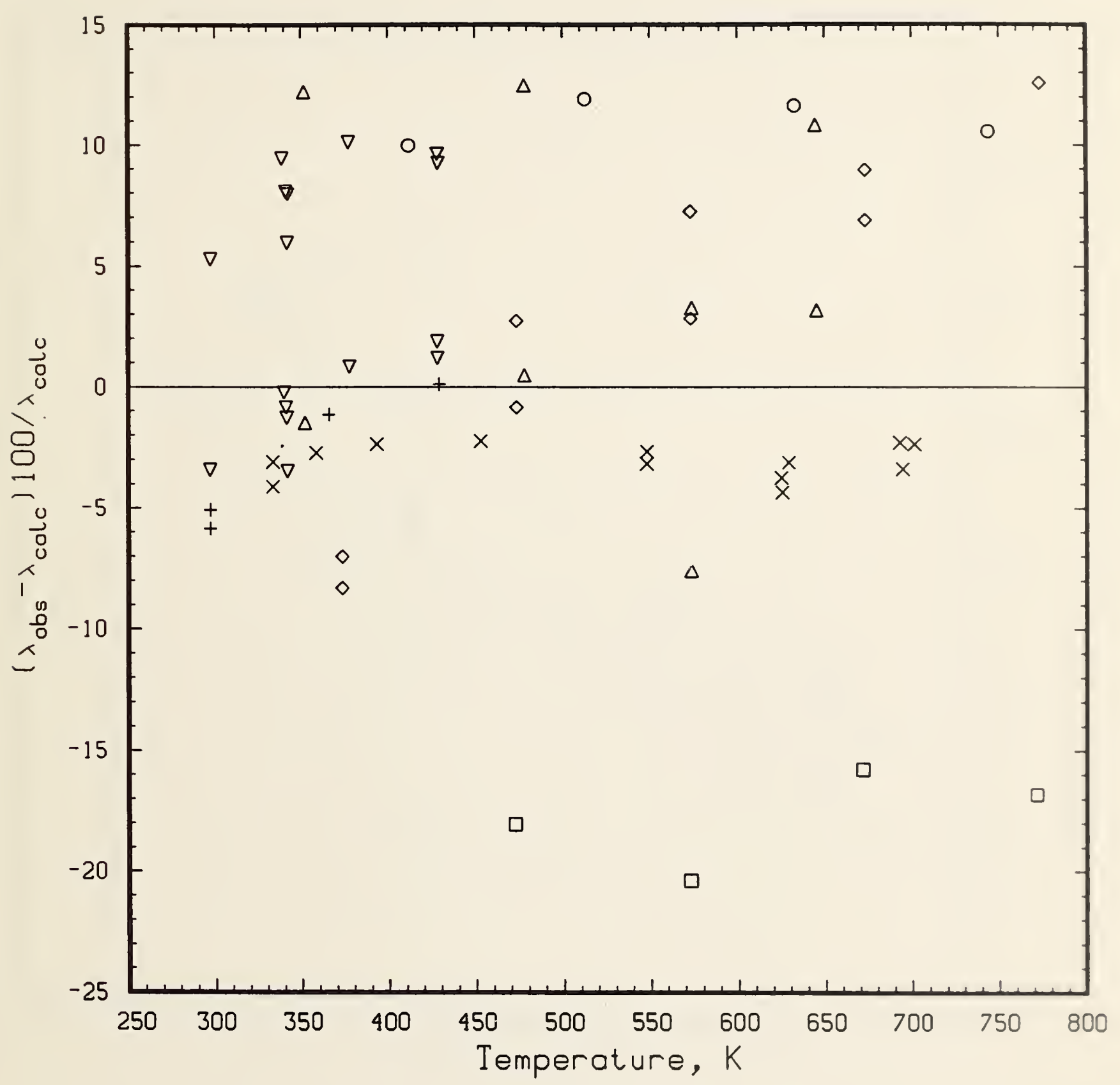

Figure 8. Deviations of thermal conductivity round-robin test results from values calculated with eq (6) for calcium silicate. 


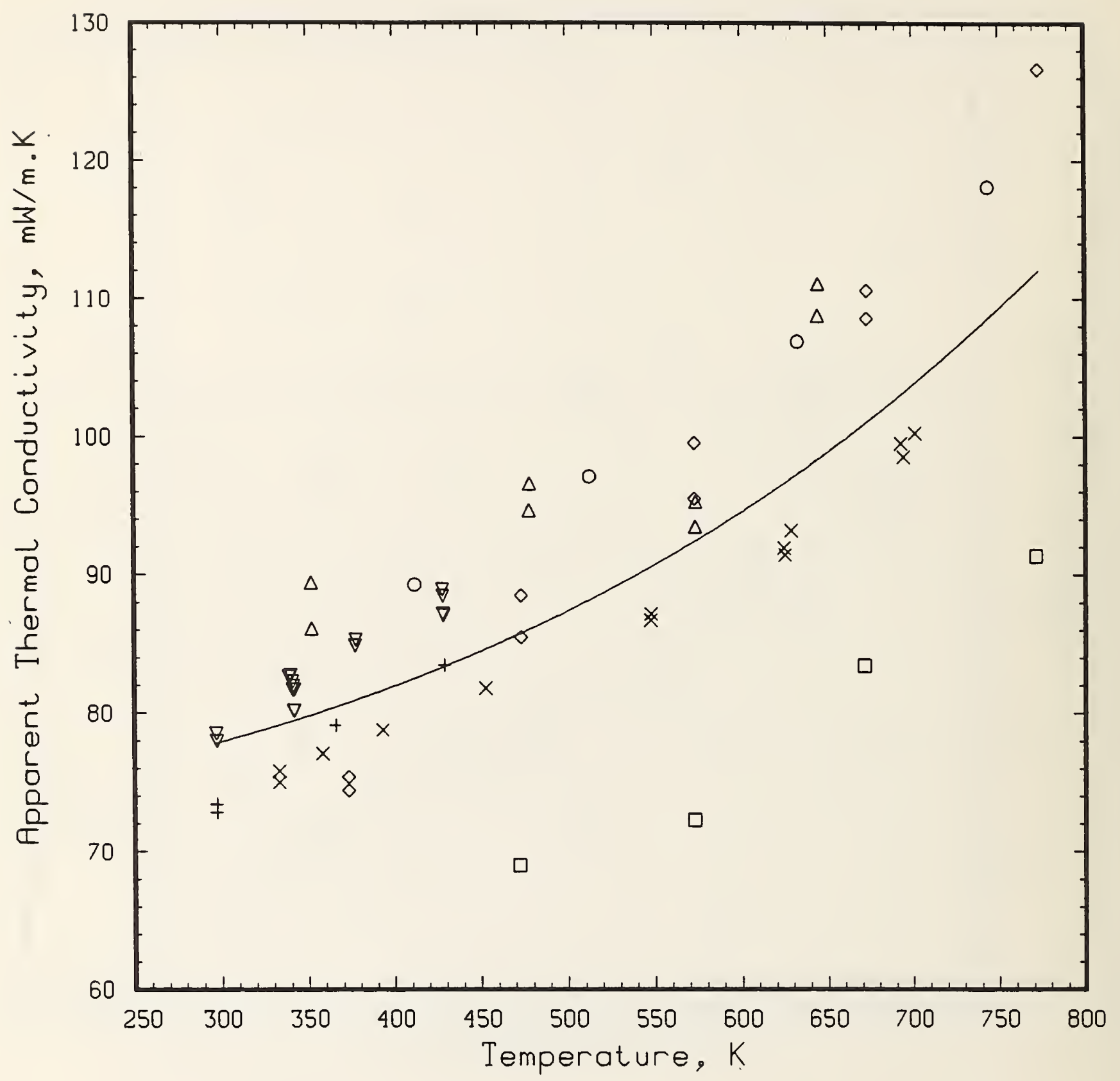

Figure 9. Thermal conductivity round-robin test results, corrected for deviation of apparent thermal conductivity from mean thermal conductivity, $75.0 \mathrm{~mW} / \mathrm{m} . \mathrm{K}$, for calcium silicate; test densities range from 320 to 450 $\mathrm{kg} / \mathrm{m}^{3}$. The solid curve is calculated from eq $(7)$. 


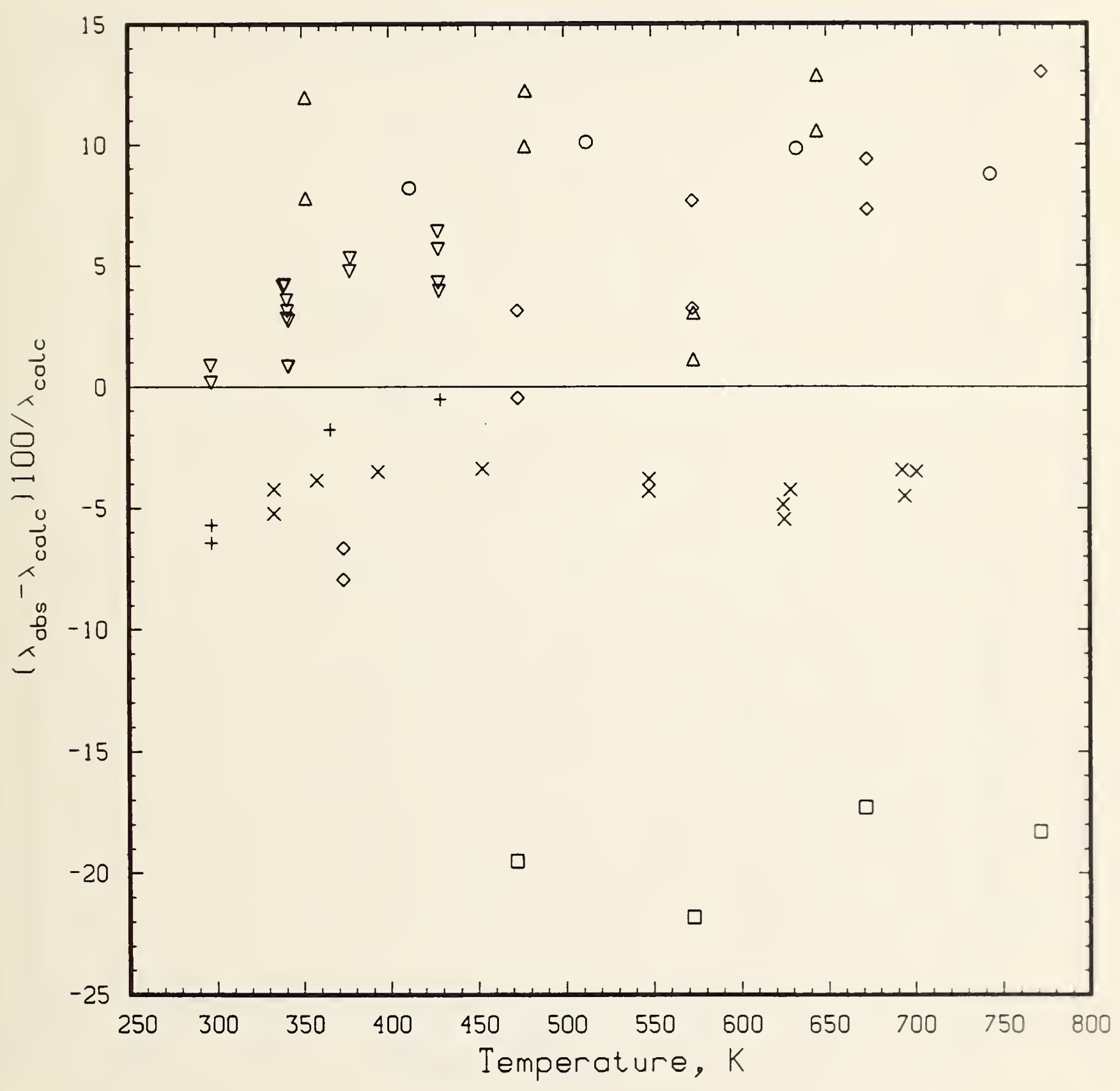

Figure 10. Deviations of corrected thermal conductivity roundrobin test results from values calculated with eq (7) for calcium silicate. 


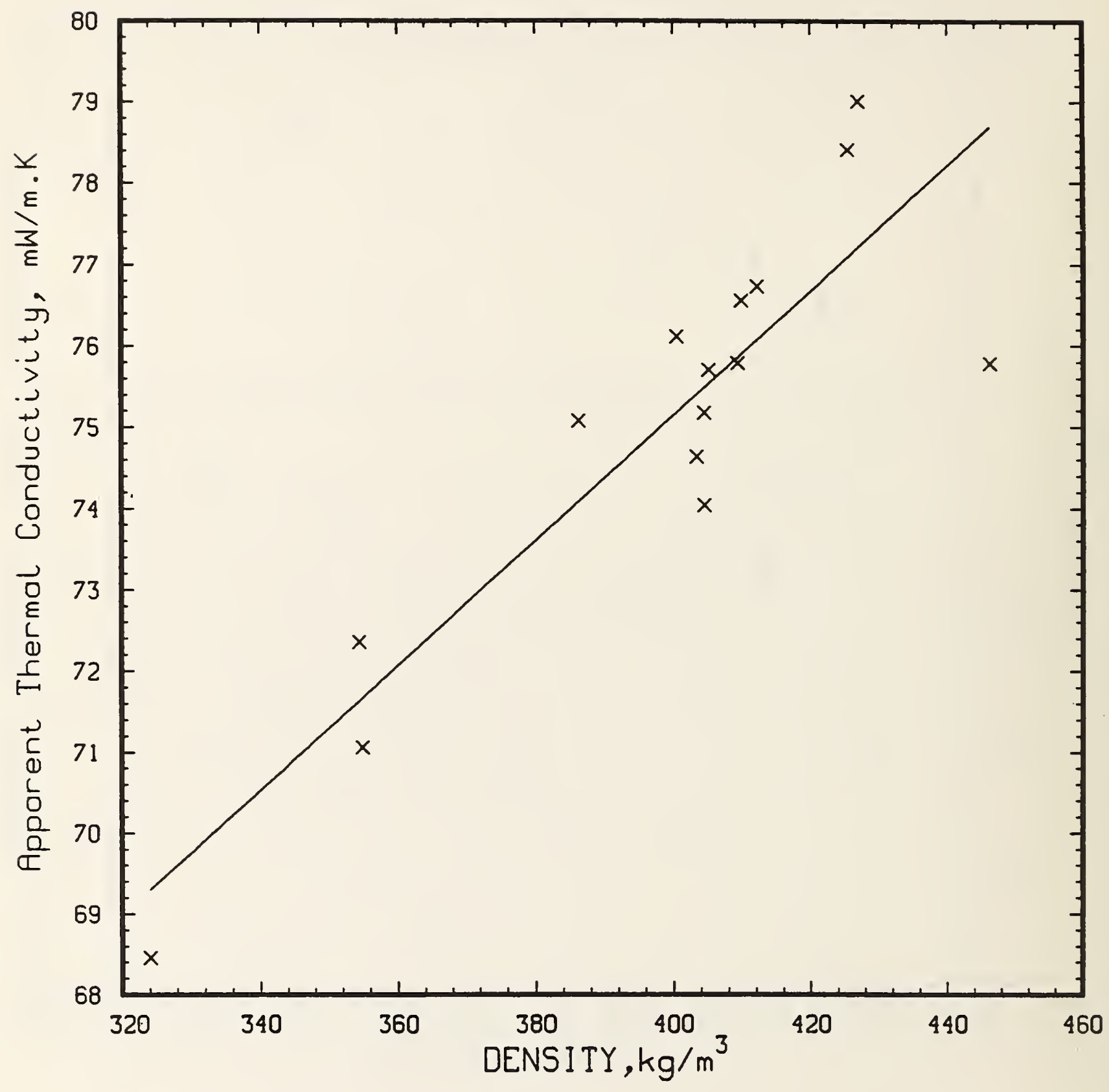

Figure 11. Thermal conductivity of round-robin specimens of calcium silicate as measured by NBS at a mean temperature of $333 \mathrm{~K}$. The solid curve is calculated from eq (8). 


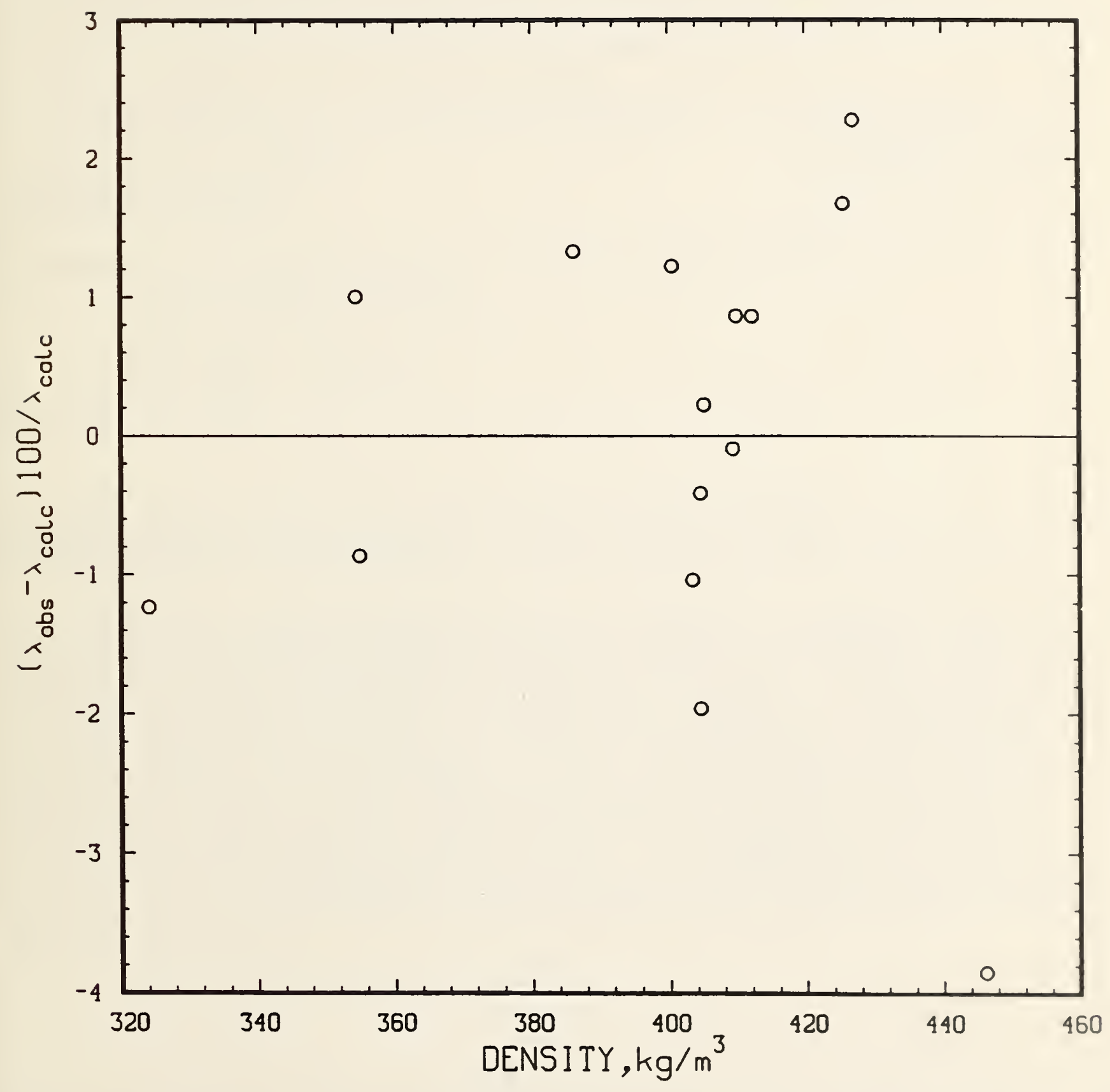

Figure 12. Deviations of thermal conductivity of round-robin specimens from values calculated with eq (8) for calcium silicate. 

NBS-114A (REV. 2-80)

U.S. OEPT. OF COMM.

1. PUBLICATION OR

REPORT NO.

BIBLIOGRAPHIC DATA

NBSIR $88-3087$

2. Performing Organ. Report No.

3. Publication Date

SHEET (See instructions)

4. TITLE AND SUBTITLE

Round-Robin Measurements of the Apparent Thermal Conductivity of Two Refractory

Insulation Materials, Using High-Temperature Guarded-Hot-Plate Apparatus

5. $A \cup T H O R(S)$

Jerome G. Hust and David R. Smith

6. PERFORMING ORGANIZATION (If joint or other than NBS, see instructions)

NATIONAL BUREAU OF STANDARDS ORNL/IA - 21428

DEPARTMENT OF COMMERCE

WASHINGTON, D.C. 20234

8. Type of Report \& Period Covered

9. SPONSORING ORGANHZATIOIN NATE AND COMPLETE ADDRESS (StraE, City. Stoto, ZIP)

U.S. Department of Energy

Oak Ridge National Laboratory

P.0. Box X

Oak Ridge, TN 37830

10. SUPPLEMENTARY NOTES

$\square$ Document describes a computer program; SF-185, FIPS Software Summary, is attached.

11. ABSTRACT (A 200-word or less factual summary of most significant information. If document includes a significant bibliography or literature survey, mention it here)

This report presents the test results and analysis of round-robin measurements of apparent thermal conductivity for two kinds of refractory insulation board using high-temperature guarded-hot-plate apparatus. The round robin was carried out under the sponsorship of the American Society for Testing and Materlals (ASTM) Subcommittee C-16.30 on Therma1 Measurements. To complete the measurement program in a timely manner the participants chose to measure different specimens, selected, however, from the same production lot. The test results for apparent thermal conductivity illustrate the inter-laboratory reproducibility as well as the temperature and density dependence. The data include the temperature range from 297 to $773 \mathrm{~K}$. The standard deviation is $7.4 \%$ for the 48 test results reported by seven participating laboratories for fibrous alumina-silica. The standard deviation is $8.0 \%$ for the 58 test results reported for calcium silicate.

12. KEY WORDS (Six to twelve entries; alphabetical order: capitalize only proper names; and separate key words by semicolons) apparent thermal conductivity; guarded-hot-plate apparatus; high temperature; refractory thermal insulation; round robin

13. AVAILABILITY

XXnlimited

$\square$ For Official Distribution. Do Not Release to NTIS

$\square$ Order From Superintendent of Documents, U.S. Government Printing Office, Washington, D.C. 20402.

XX Order From National Technical Information Service (NTIS), Springfield, VA. 2216I

14. NO. OF PRINTED PAGES

32

15. Pice 


